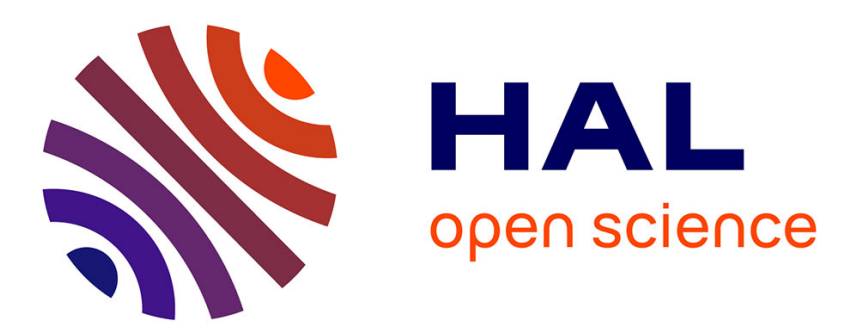

\title{
Language endangerment and revitalisation as elements of regimes of truth: shifting terminology to shift perspective \\ James Costa
}

\section{- To cite this version:}

James Costa. Language endangerment and revitalisation as elements of regimes of truth: shifting terminology to shift perspective. Journal of Multilingual and Multicultural Development, 2013, 34 (4), pp.317-331. 10.1080/01434632.2013.794807 . halshs-00825525

\section{HAL Id: halshs-00825525 \\ https://shs.hal.science/halshs-00825525}

Submitted on 9 Dec 2016

HAL is a multi-disciplinary open access archive for the deposit and dissemination of scientific research documents, whether they are published or not. The documents may come from teaching and research institutions in France or abroad, or from public or private research centers.
L'archive ouverte pluridisciplinaire HAL, est destinée au dépôt et à la diffusion de documents scientifiques de niveau recherche, publiés ou non, émanant des établissements d'enseignement et de recherche français ou étrangers, des laboratoires publics ou privés. 


\title{
Language endangerment and revitalisation as elements of regimes of truth: Shifting terminology to shift perspective
}

\author{
James Costa $^{* 1}$
}

ICAR / Institut français de l'éducation (Ecole Normale Supérieure de Lyon), Lyon, France.

This paper seeks to explore how the language endangerment/revitalisation discourse was gradually established as a new Foucauldian regime of truth. I characterise this regime of truth as one that not only essentialises the link between language and community, but also as one that constructs communities as homogeneous and seeks to minimise internal and external conflict. Through the example of how this discourse is becoming dominant in France, I then suggest that there are alternative ways of looking at minority language processes, and draw on works developed in France in the 1980s in the Occitan school of sociolinguistics to propose an approach centred on social actors and processes rather than on languages. I thus propose that one way of analyzing (and responding to) 'language endangerment' may reside in looking at it from a different perspective such as the one developed by Robert Lafont around the Occitan case.

Keywords: Language revitalisation; language endangerment; discourses of endangerment; regimes of truth; sociolinguistics; social theory

\section{Introduction: Language endangerment and revitalisation as regimes of truth}

What we now call language revival movements originated in nineteenth century Europe and have existed for over 150 years. They can be defined as a type of social movement that justifies its proposed action on the basis of a semiotisation of language in discourse. That is to say, such movements mobilise language in order to voice concerns (and demands) of a social nature, such as issues of social class, inequality, domination and so forth.

\footnotetext{
*Email: james.costa@ens-lsh.fr
} 
The terminology now in use in academia to describe such processes, namely language revitalisation, understood as a reaction to language endangerment, has only become current over the past twenty years (Hale et al. (1992) is often quoted as the catalyst of the contemporary concern with language endangerment).

In this context, both 'endangerment' and 'revitalisation' function as keywords, in the sense of Williams (1985) - words that bear accepted meanings and provide an appearance of continuity - but the analysis of which often reveals variation and contestation. Those terms can therefore be analysed not only as concepts, but also as spaces that allow different interests to manifest themselves, and that can be invested in or disinvested from by different social actors for various reasons. One could thus ask: who invests in those terms, and to what ends? With what consequences? And what alternative approaches to contemporary minority language issues are available that may allow us to analyse the same processes from a different, possibly broader, perspective? ${ }^{2}$

The genealogy of this joint terminology is of considerable interest: while they have now permeated not only the media but also language activist groups in the Americas as well as in Europe, the terms language endangerment and language revitalisation arose in North American linguistics and linguistic anthropology. As such, they perpetuate North American anthropology's long-lasting programme of 'salvage anthropology' - preserving indigenous languages and culture while it is still possible, for future generations to find out about, or even to revive, as part of a long-lasting battle against ethnocentrism (see Lewis 2001). However, language 'endangerment' and 'revitalisation' are now leading lives of their own; several research programmes, responding to a wide array of interests and agendas, are being conducted in their names worldwide.

This article argues that while endangerment and revitalisation have separate genealogies, they are now part of the same package, and serve to describe and analyse a wide 
array of processes worldwide. They bring social issues under the same framework that may otherwise have been analysed in terms of land claims, for example - as could often be the case in Latin America (e.g., Pivot to appear, on the Rama area in Nicaragua). Framing sociocultural issues in linguistic terms has a double effect: while it allows otherwise socially condemned voices (Lafont 1971) to be heard on a national and international scale, it also masks many other social issues at play; it also often serves to reproduce structures of inequality both between and within social and cultural groups (see Speed 2005 on the effects of the promotion of cultural rights in Mexico).

I therefore suggest that language 'endangerment' and 'revitalisation' can be understood as part of 'regimes of truth' (Foucault 1980), i.e., 'types of discourses a society accepts and makes function as true' (Weir 2008, 368). Promoting socio-economic rights through language may therefore serve to naturalise constructed links between language, culture and ethnicity that lock peoples into an imagined past and potentially deprive them of a future. Framing socio-economic discourses through language may also induce language-related solutions, which in turn can easily overlook other types of solutions to otherwise formulated problems.

However, the endangerment/revitalisation approach to linguistic minority groups is, arguably, but one way of framing issues in which language plays a significant role. In the course of becoming dominant, this approach was imposed at the expense of others. Other approaches, such as those developed by Robert Lafont in southern France for example, permitted, on the one hand, social dimensions other than language to gain more consideration, and, on the other, allowed language to be seen as but one parameter in otherwise complex social problems that involved reshaping issues of power and domination.

In order to explore the questions outlined above, I will look at the development of 'revitalisation' as a keyword in North American anthropology and linguistics to show how, as a result of the portrayal of diversity as inherently desirable, language has gradually become a 
primary focus, rather than the focus being on social processes or people. This will allow me to characterise the endangerment/revitalisation regime of truth as a way to implement new sets of attitudes towards language rather than towards other types of socio-economic issues. I will then trace the adoption of the 'revitalisation' paradigm in France, showing how it is gradually masking former ways of looking at processes of minorisation, developed in particular in Occitan sociolinguistics, an approach I became acquainted with during my Ph.D. work in Provence (Costa 2010). Finally, I will outline possible alternative ways of looking at minority language contexts that concentrate not on language but rather on social processes. In other words, I wish to suggest that one way of taking action with regard to 'language endangerment' might well be, at least in a number of cases, to look at the processes involved from an altogether different perspective.

\section{'Before it is too late'}

Vitalistic metaphors have long been used in dialectology or anthropology (Cameron 2007), and the idea that languages can live or die was common throughout the twentieth century. The idea that languages can be endangered is more occasional, and concerns for linguistic renaissances were, until the $1980 \mathrm{~s}$, left to activist movements.

In this section, I sketch the origins and development of the discourse of endangerment and revitalisation. A long-standing tradition of research in American linguistics does refer to language obsolescence (e.g., Swadesh 1948) or language death (e.g., Dorian 1981). Yet it was the American anthropologist Anthony Wallace who first used the term 'revitalisation' (Wallace 1956, 2004; see also Costa [2010] for a commentary) to describe a type of conscious, organised culture change. 
Wallace originally employed the term to discuss a new religious cult, led by a local prophet, Handsome Lake, which developed among the Seneca Iroquois in the nineteenth century. The aim of the revitalisation movement was to provide a solution to the recurrent outbreak of conflict that was plaguing the community as a result of contact with European colonists.

An explicit concern for 'language revitalisation' later re-emerged at the crossroads between several events at the beginning of the 1990s (see Grinevald \& Costa 2010). At that moment, two types of discourses were to join forces: the celebratory discourse on the $500^{\text {th }}$ anniversary of the discovery of the Americas by Columbus on the one hand, which was met with much anger among Native American groups. On the other hand, the prolonged work of linguists with Amerindian communities, particularly in Central America, led to the idea, expressed by the communities themselves, that something had to be done to help preserve languages that were vanishing fast. This conjunction of events led to the organisation of a symposium on language endangerment at the Linguistic Society of America's 1991 meeting (the proceedings were subsequently published as Hale et al. 1992; see also Robins and Uhlenbeck 1991).

In the above collection of papers, Craig (re-)introduced the term 'revitalisation' in her contribution on Nicaragua (Craig 1992), to translate the Spanish rescatar - a term used by the Sandinista government to describe the mission that had been assigned to her as a linguist working with the Rama people and language (Grinevald [Craig], personal communication, 2011). Since then, it has been used in a wide number of contexts by a significant number of linguists, sociolinguists and anthropologists.

The concern for the preservation of language diversity does however stem from an older tradition, namely the long-standing agenda in North American anthropology of documenting and salvaging indigenous languages - that is, writing them down and recording 
them for eternity, while this is still possible. This tradition is rooted in the works of Boas and, later, of Sapir and Whorf (see Woodbury 2011). Indeed, Whorf is himself credited by Fishman (1982) with having given rise to works on language preservation. Fishman considers that a third Whorfian hypothesis (after linguistic relativity and determinism) is one that champions linguistic diversity for the benefit of all mankind. This documentation agenda was initially motivated by the disappearance of the frontier in western America. In early twentieth century anthropology, as now in several sectors of linguistics, similar dynamics were at play: they rested upon the Boasian premise that what is uniquely human is diversity and variability (Bauman \& Briggs 2003, Chapter 8).

In the words of the American anthropologist Jacob Gruber (1970, 1297):

[...] the needs of salvage then [in the early $20^{\text {th }}$ century], so readily recognised through an awareness of a savage vanishing on the disappearing frontier of an advancing civilisation, set the tone and the method for much that was anthropology in the earlier years of its prosecution as a self-conscious discipline.

Though the American frontier may now be gone, other types of frontiers still exist in America as well as in other parts of the world - psychological frontiers between social categories for example. They are sometimes seen as rapidly disappearing as neoliberal capitalism makes its way across the planet, reshaping the diversity of both thought and social organisation locally as well as globally, and leading to the spectre of the advent of a form of global homogenisation (see Cameron 2007). This is often presented as a dire moment in some circles, where the disappearance of linguistic diversity is connected to human rights issues as well as to the loss of biodiversity (e.g., Skutnabb-Kangas 2009).

Tracing the complete genealogy of 'endangerment' and 'revitalisation' would require more space than allowed here. Yet a selection of quotations will show that similar dynamics, 
relating to industrialisation and the advance of modernity, manifest themselves in both early twentieth century anthropology and in contemporary works on language revitalisation.

On the one hand, in The Study of Man, Haddon (1898, xxiii) thus remarked:

Now is the time to record. An infinitude has been irrevocably lost, a very great deal is now rapidly disappearing; thanks to colonisation, trade, and missionary enterprise, the change that has come over the uttermost parts of the world during the last fifty years is almost incredible.

On the other hand, more recently and in less celebratory language, Hinton $(2003,44)$ wrote: 'The processes of empire, industrialisation, and globalisation have made casualties out of indigenous languages and cultures' (see also Bell, this volume). It follows that, in a context of modernisation and decolonisation, uniqueness axiomatically requires saving for the greater benefit of all humankind (Fishman 1982; and, for a critical perspective, Cameron 2007), hence the need to rekindle diversity.

The logic behind documenting (then) and revitalising (now) is thus rooted in the same type of outlook on social reality: 'something' can - and should - be done (by whom is not always clear): whether it be by documenting, archiving, saving (for the future) or by revitalising (for the time being). This introduces a dichotomy between good (diversity, preservation, revitalisation, efforts to save languages or cultures) and bad (modernity, uniformity, homogenisation, and in fine, language shift). That is, some people (usually, in the endangerment/revitalisation discourse, 'Indigenous people') are assigned the role of being the custodians of linguistic diversity, not (only) for their own good, but also for the benefit of all humankind. 
Additionally, in both early twentieth century anthropology and in early twenty-first century linguistics, languages and cultures were seen predominantly as monolithic artefacts that required saving as such, and not as evolving social practices treated as the products of human interaction. One of the dangers of essentialising the connection between language, people and identity is of course the construction of certain types of rights dependent on the practice of an indigenous or local language. In Mexico for instance, Muehlmann (2008) remarks that state benefit to the Cucapá, an indigenous group in the Colorado delta region, is made available on the condition that the population can justify the practice of an indigenous language. Similarly, as Simpson (this volume) observes for Australia, 'knowledge of the songs and ceremonies associated with an area of land was sometimes critical in State recognition of traditional ownership'.

In associating certain groups with linguistic diversity, preservationist discourses naturalise an unexamined link between people and language. Putting abstract notions forward (for example 'our rich human diversity', 'humankind') and turning particularistic issues into universal ones, those discourses tend to objectify 'languages' and tend to concentrate on saving 'languages' rather than on the socio-economic issues faced by people (see Cameron 2007; Hill 2002 for a linguistic anthropological perspective on treasuring languages; Labov 2008 for a sociolinguistic perspective; see also Dobrin et al. 2009 on commodification of languages in the documentation rhetoric).

While discourses on language endangerment and revitalisation are often tied to discourses of social justice, the premises upon which they rest are frequently rooted in principles that tend to naturalise connections between language and identity, and to divert attention from other types of socio-economic issues in favour of linguistic ones. For example, is revitalising a language an adequate response to - or way to address - threats to land, property or to environmental concerns, in turn caused by the very structure of the countries 
that concomitantly promote linguistic diversity? (See also Hale 2005; Speed 2005; Good 2012.)

\section{Erasing people and conflict in language revitalisation studies}

Language revitalisation is strikingly, for the most part, presented as being about language, not about people (but contrast Bell, this volume, for example). This section will characterise the regimes of truth generated by the revitalisation discourse in terms of erasing 'people' on the one hand, in favour of 'language', and of levelling internal conflict, on the other. Here is shown how the question of language revitalisation is often (albeit mostly unconsciously) reduced to a matter of 'attitudes', understood in its simplest definition as 'a disposition to react favourably or unfavourably to a class of objects' (Sarnoff 1970, 279). In cases where individuals tend to react unfavourably to a language deemed (often by others) as their own, language revitalisation becomes a matter of getting people to react favourably to something thought to be to their benefit.

A first example is taken from Meyer and Cuero (2011), an account of a language revitalisation programme in Baja California, in Mexico. Interestingly, the authors frame the loss of linguistic identity in terms of erasure during the process of the construction of the Mexican nation-state: 'Thus in Mexico, as in other countries, indigenous people are just “Mexicans". Their indigenous identity is erased.' (Meyer and Cuero 2011, 58).

In addition to the alienation described above, the authors depict a situation of poverty and dire socio-economic conditions. But the point they make is not that language is not itself a priority in such conditions, but rather that those economic conditions obscure the intrinsic value of the indigenous language and of the revitalisation programme: 
Many language programs have sprung up and fizzled. In general, it came down to the situation that people did not want to teach the language unless they were paid for it. [...] Unless people were more secure within themselves, and hence probably had a higher socio-economic level and, with that, a better education, they could not see the point of revitalisation for itself. (Meyer and Cuero 2011, 59)

The assumption of the authors is that the value of the language does not naturally depend on the state of the market in which it is exchanged (i.e., on its social or economic value), but rather rests within the language itself. Revitalisation is not questioned as such - what is questioned are the attitudes displayed by speakers. Yet, of the speakers themselves we learn very little from the article - other than that they are poor. What the authors choose to put forward is the language, and the revitalisation programme that serves it; individuals exist as 'speakers' of language X or Y (I intentionally use Fishman's (1991) terminology here to show that the tendency to objectify language and to essentialise the link between communities and language is not restricted to linguistics or linguistic anthropology; see Muehlmann 2011 for an example of how individuals can resent being seen primarily as speakers rather than as, say, fishers, craftspeople, etc.).

A second example is taken from Kroskrity (2009), who justifies the existence of language revitalisation among the Western Mono of North Fork and Auberry in Central California and among the Arizona Tewa. Because of internal conflict among individuals, Kroskrity characterises both groups as requiring 'prior ideological clarification' (a term introduced by Fishman 1991) so as to achieve a desirable common goal, i.e., the revitalisation of their languages. Clarification is seen as a means to erase unnecessary conflict among those groups, thus linking language reclamation and indigenousness (the language is a desirable part of what it means to be indigenous), and at the same time homogenising those groups (for 
all indigenous people, language revitalisation is intrinsically desirable). Therefore, while aiming to analyse internal conflict among the Tewa, Kroskrity $(2009,80)$ writes:

[...] by treating ideological clarification, not as an afterthought, but rather as a precondition and an ongoing process for successful language renewal, communities can avoid, or at least minimize, the kinds of conflicts and breakdowns in cooperation that can prove disastrous for such projects.

Apparently the project aimed to minimise conflict and to help promote revitalisation (or 'renewal'), though the term and its implications are not explored. This illustrates how in a 'language revitalisation' approach, linguists or anthropologists tend to downplay the fact that processes of language change are outcomes of prolonged contact between groups (in this case of a colonial nature), inevitably tied to a diversity of stances and positions among community members, and may be viewed by some community members as acceptable or desirable (again, see Bell, this volume, for an alternative view). Instead, the revitalisation approach favours the elaboration of a consensual and homogeneous view of communities where the desirability of 'reviving' a language is neither questioned nor questionable. Issues and debates become attitudinal problems that may be addressed in order to achieve necessary consensus. Consequently, this approach, centred on homogenised groups, allows the erasure of other types of social divisions, such as social class.

Both attitudes outlined above in the two examples are embraced by Hinton $(2003,47)$, according to whom 'in the 1970 s and 1980 s, many communities did not fully recognize the extreme danger facing their languages'. In viewing 'communities' as dwelling outside organised realms of effective power, occupied by the coloniser and the outsider, not only does Hinton downplay social processes of domination and asymmetrical contact in favour of 
an analysis in terms of larger, de-personified, historical processes such as globalisation, she also misses the tensions and disputes that inevitably coexist within those groups. Further, she fails to address the very fabric of power and domination and the participation of members of dominated groups in their own domination (see Foucault 1980, 118-119]). It is therefore not a matter of 'not fully recognising' danger, but of symbolically investing various domains (or not) as symbols of resistance. Yet, despite Hinton's implication, language is not inherently a symbol of resistance through a display of identity: it is only so in particular contexts. The 'endangerment'/'revitalisation' discourse emerged in a historically situated and socially constructed setting.

\section{Importing language revitalisation into French sociolinguistics}

The 'endangerment' and 'revitalisation' discourse is by no means restricted to North America; in fact, it has become dominant worldwide due to the subscription to it of such institutional bodies as UNESCO (e.g. Moseley 2010). To understand how it is being imposed or adopted, and how previous, local traditions of research are being displaced by the new paradigm, we will draw on the example of France. It is worth mentioning however that a similar enterprise could be conducted about North American scholarship, where more critical perspectives also existed before the 1990s - see Hill and Hill (1980) for example - and have continued until now (Hill 2002).

The emergence of the new discourse was reported very early in the French social sciences, through the publication of a special issue of the journal Diogène $\left(1991, \mathrm{n}^{\circ} 153\right)$ that presented the translations of four articles from Robins and Uhlenbeck (1991). However, those articles dealt with faraway linguistic contexts, and in 1992 the renowned French linguist Georges Mounin published a 'Discussion on the Death of Language' (Mounin [1992] 2006) 
that echoed the publication of Diogène. There he deemed the new field of research mostly absent in French linguistics:

This unused collection of documents [i.e., the articles published in Diogène] may surprise more than one specialist of European or French linguistics, for whom issues related to Alsacian, Breton, Occitan, Basque, Valdôtain, or even Flemish often rest at the margins of current preoccupations and research; and, unless I am mistaken, they seldom appear in our journals. (Mounin [1992] 2006, 182, my translation)

Other reasons for the potential lack of interest in the new field of language endangerment included, according to Mounin, the absence of a fixed terminology, and the interdisciplinary nature of the new domain.

It was therefore not until 1999 that the endangerment discourse made its way into French linguistics, when the Société de Linguistique de Paris organised a conference entitled 'Les langues en danger'. Participants included specialists of minority languages of France, such as Occitan, as well as linguists working in Oceania and Latin America; the proceedings were published in 2000 .

The year 2000 also saw the coming together of several types of linguistic discourses in France: those on 'endangered languages', but also discourses surrounding issues of minority rights brought about by the signing and ratifying of the Council of Europe European Charter for Regional or Minority Languages. In turn, those discourses met existing ones about the threat that English allegedly posed to French at an international level.

The ideological climate was therefore ripe for the linguist Claude Hagège to publish that very same year his book entitled Halte à la mort des langues [Stop the death of languages] (Hagège 2000), aimed at a wide audience and later translated in English as On the Death and Life of Languages (Hagège 2009). ${ }^{3}$ The rhetoric developed by Hagège was new to 
the general public in France, especially coming from such a prominent authority, and immediately attracted attention on the part of minority language activists. Hagège combined new arguments taken directly from the endangered languages paradigm, in particular figures and rates of endangerment (such as the famous $50-90 \%$ rate of language disappearance before the end of the century, and the claim that one language disappears every fortnight), with older elements of discourse linked with the defence of the French language.

Drawing heavily on the endangerment and revitalisation discourse, Hagège's book is rife with vitalist metaphors. For example, languages are described as 'purveyors of life' (the title of Chapter 1) that need to be resurrected. The final chapter deals with 'resuscitating' languages and presents cases such as those of Hebrew in Israel, Cornish in the UK, and Rama in Nicaragua.

Most importantly, and as in the discourses outlined in the previous section, social actors are erased in favour of languages, and both internal and external social conflicts are masked; instead the reader is presented with an abstract conflict opposing 'languages' as entities rather than people caught in issues of power, domination and minorisation. Hagège achieves this through formulating the problem of language endangerment using general, impersonal sentences where agents are not identified (e.g., 'I recalled, however, that new languages were born, or were resuscitated during the $19^{\text {th }}$ and $20^{\text {th }}$ centuries [...] One can resuscitate a language' [Hagège 2000, 363, my translation]).

The endangerment/revitalisation terminology has since then been largely adopted by language advocates in Brittany, southern France and other parts of the country, and is often connected with a rhetoric that links language endangerment with biodiversity endangerment. Yet, the vocabulary and rhetorical devices used by Hagège contrast strongly with the writings of sociolinguists such as Robert Lafont, Jean-Baptiste Marcellesi and others in the 1970s and 
1980s, whose focus was, as the next section illustrates, on speakers and social processes of domination and alienation.

\section{'Rolling up diglossia,' or looking at minority languages from a different perspective}

Occitan sociolinguistic discourse, like the endangerment/revitalisation approach, had as its object the contexts of minority languages. As such, it provides one alternative model worth examining. In contrast with the works outlined in previous sections, this approach does not seek to influence the attitudes of speakers towards their language; rather, it seeks to attend to the very ideological fabric of the social environment of individuals, part of which is embedded in linguistic form, language use, and discourse on form and use.

Robert Lafont was a prominent Occitan ${ }^{4}$ linguist and sociolinguist who taught at the University of Montpellier for several decades and considerably influenced Occitan sociolinguistics in the 1970s and 1980s through his prolific body of work in linguistics, sociolinguistics, sociology, economics and literature (see, in particular, the collection of sociolinguistics articles in Lafont 1997).

Before I present more details about Occitan sociolinguistics, I wish to elaborate upon the Provençal context in which I conducted fieldwork between 2007 and 2011, as it will explain why I sought to distance my work on minority language sociolinguistics away from 'language' issues to concentrate more on 'speakers' issues. I initially moved away from the discourse of endangered languages precisely because of a situation similar to that outlined by Kroskrity (2009), parts of which are analysed below.

During my time in the field, I identified (at least) two sets of radically different positions towards the local language, in terms of language naming, linguistic boundary setting and preferred orthography (see Costa and Gasquet-Cyrus, to appear). To simplify the 
matter, one may say that a 'Provençalist' discourse claims that Provençal is a language in its own right, spoken in historical Provence and codified in the nineteenth century by Frederic Mistral. Conversely, an 'Occitanist' discourse claims that Provençal is in fact a dialect of a larger language, Occitan, spoken in most of the south of France (the 'Midi'), and can be written with an orthography based on the one in use in medieval times that allows written intercomprehension throughout the linguistic territory.

While this conflict leads to the current impossibility of implementing an institutional language policy in the area, I have argued elsewhere that the situation is best understood as a set of ideological debates that are as much part of the very fabric of the region as the language itself (Costa 2011). Both sets of discourse seek to generate and impose new regimes of truth, and attempts at ideological clarification would inevitably be welcomed with hostility and would certainly end in the betrayal of some form of adherence of the expert to one side or the other.

A scientific examination of situations of language revitalisation cannot thus be premised upon the idea that such processes are inherently desirable, that languages should necessarily be saved. It is indeed the very nature of regimes of truth not to be true per se, but to represent points of view on how to construct events into situations, situations into problems, and problems into solutions. Since in the Provençal case no stance regarding language could be taken as either 'true' or 'false', the bitter debates that took place locally needed to be explored in other ways than through this overwhelming dichotomy.

A new direction came from reading the works of the Occitan historian Philippe Martel, whose work is related to Occitan sociolinguistics. According to Martel, 'the bottom line of the linguistic problem in France is not ethnic: no "Francian" people ever came to impose its language to other subdued people. It is however undeniably connected to issues of social class' (Martel 2001, 383, my translation). As mentioned above, issues of social class, 
especially within language minority groups, are typically among the ones that the endangered languages paradigm rarely addresses.

This provided the impetus for looking at the Provençal situation through new lenses, and allowed me to suggest that the ongoing conflict in Provence corresponded to different manifestations of geographic or social class conflicts over a period of more than 150 years. In its later form, this conflict allowed social actors to actualise and give substance to otherwise disembodied processes such as globalisation. Depicting one group, the 'Occitanists', as middle-class agents of globalisation allows the other group, the 'Provençalists', to (re)present themselves as rural defenders of true Provençalité in the superordinate context of increased globalisation, and to give that process substance, shape and an identifiable figure.

I now return to Occitan sociolinguistics. Martel had been a student of Lafont in the 1970s, at a time when French sociolinguistics developed around several poles in Paris, Rouen, and Montpellier. The last two centres were particularly instrumental in developing a sociolinguistics of minority groups, particularly in Corsica (Rouen, around Marcellesi) and in the Occitan-speaking regions (Montpellier, around Lafont). The Montpellier school itself developed in close collaboration with the Catalan school of sociolinguistics based in Barcelona (together, they are also known as 'native sociolinguistics', or 'peripheral sociolinguistics').

Central to the works of Occitan sociolinguistics was the notion of conflict, expressed though the redefinition of the notion of diglossia, seen not as a stable situation but rather as representing conflicting interests at play between dominant and dominated groups, which would inevitably result in either assimilation to the dominant group or normalisation. The latter term was to be understood as the (re-)establishment of all functions normally assigned to a standardised language. 
Occitan sociolinguistics, however, did not focus on saving a language, seen as a constantly evolving social practice, but on liberating otherwise socially condemned voices (Lafont 1971). This was to be achieved through 'rolling up diglossia', i.e., raising the social position of those who spoke Occitan or French with an Occitan accent through the renegotiation of the respective roles of both languages on a common linguistic market (see also Bourdieu 1977).

In addition to the points outlined above, Occitan sociolinguistics can contribute to general sociolinguistics in the following ways: sociolinguists (and also, importantly, activists) ought to consider social processes rather than just language, and should avoid falling into the trap of identity, which in turn ethnicises what are fundamentally social issues of alienation, domination, and resistance. Occitan is not the preserve of a unique people with a distinctive identity; instead it is a way of expressing sets of (currently) marginalised voices. According to Lafont, nationalism was a consequence of an identity approach, which was another trap to be avoided as it locked a homogenised people in a single way of looking at history, and potentially denied them a future. Accordingly, sociolinguistics should deal with social conditions ultimately affecting (or not) patterns of language use, rather than language.

Yet, while this type of discourse elaborated in the 1970s and 1980s has not totally disappeared from the French academic sociolinguistic scene, it is now far less audible either in the media or among language activists, partly because it lacks a central feature of the endangerment/revitalisation discourse, namely the sense of urgency and possible moral panic that the latter provides. 


\section{Conclusion and discussion: Language, ideologies and language revitalisation}

The ideas examined above contribute to a discussion on the connections that can be made between the development of the endangerment/revitalisation discourse and the rise of other, seemingly unrelated, neoliberal economic discourses.

This paper has regarded the emergence of the language endangerment/revitalisation discourse as leading to the construction of a regime of truth that provided a grid to generate solutions to a perceived state of stress or crisis. This discourse has tended to erase local, social specificities in favour of an essentialising discourse that focuses on languages rather than on people, and in turn homogenises communities around issues of language and collective identity. This process potentially obscures other pressing issues, of social class for example.

It was then suggested that alternative ways of looking at language issues among minority groups were developed in several places, and are still available. Those approaches permit an analysis in terms of social actors and processes, and do not necessarily posit that attitudinal change is necessary to attain a greater good defined from the outside. Instead, they provide social actors with an analysis of ideological positions that run through a particular group. The approach outlined, based on the work of Lafont, aims at liberating otherwise socially condemned voices, by making them heard and by changing their position on what I termed, after Bourdieu, a common (unified) linguistic market. Shifting terminology, and reframing issues with other metaphors, thus allow for different approaches to be developed, and for contrastive solutions and policies to be devised.

In fact, as regimes of truth, discourses on endangerment and revitalisation are but one way of looking at a series of social issues in a range of very dissimilar contexts that tend to be regrouped under a reduced number of keywords. Such discourses are accordingly convenient in many respects. They allow minority groups to gain access to the media, and they allow 
governments to integrate minority languages into their national narratives. Yet ultimately, what is focused upon is possibly more 'our rich cultural heritage', an often vacuous notion that draws on a global discourse of immaterial (intangible) heritage, and downplays the social processes that lead to situations of minorisation in the first place (see also Cameron 2007).

To understand what is really at play in a community, 'languages' may therefore not be the best place to start when looking at processes that apparently involve the recuperation of former linguistic practices. Discourse on language(s), however, who utters it, to what ends, and importantly, who doesn't use it, may be an excellent place to start (see Simpson, this volume). Debates on linguistic issues are typically one way of gaining access to many other elements at stake (Blommaert 1999) as the language entry may provide a window onto the ideological functioning of a group.

Finally, the endangerment/revitalisation approach may perhaps prove beneficial in some contexts, particularly in such contexts where regional languages are no longer central to the social and political life of the areas where they are/were spoken. That is, where they are less likely to do any immediate harm. Yet I suggest that looking at minority language settings from different points of view - ones that address issues of social actors, of power circulation, and of social class, ones that concentrate on the local without immediately assigning it to a global category such as 'language endangerment' - might also be a form of response that anthropologists and linguists can propose to the people with whom they work.

This last section intends to go beyond this. The elements of reflection on language endangerment I have presented do not exist within an ideological vacuum. They are, I argue, deeply connected to the rise of neoliberal economic discourses. As I outlined above, the endangerment/revitalisation discourse is itself rooted in the North American anthropological discourse of salvation. This discourse was, however, able to flourish again in North America, 
and subsequently across the world, for a number of reasons, discussion of which is beyond the scope of this article.

Indeed, while the commemorations of the $500^{\text {th }}$ anniversary of the so-called discovery of the Americas by Columbus sparked new claims and demands at the end of the 1980s, this discourse received a warm welcome in several parts of the continent from new economic (neoliberal) discourses that were gaining ground at the same time and that looked favourably upon the development of new multicultural policies. According to Speed (2005), in the case of Mexico, while Indians are busy defining and debating which ethnic groups they belong to and what language they (ought to) speak, they are not busy voicing other types of social demands. Interestingly, Speed also remarks that in Mexico multicultural and linguistic rights were granted to indigenous communities at the same time as other types of rights, such as rights to communal land, were scrapped.

I therefore suggest that a connection may be established between the flourishing of discourses that tend to essentialise links between language and communities, and to homogenise groups, and others that promote cultural rights as a way to erase other social or territorial rights.

In France as well, one could remark that the endangerment and revitalisation discourse started to gain momentum precisely at the moment when the general political discourse was gradually affected by a tendency to ethnicise different types of social problems (Amselle 2011), in particular in connection with the suburbs of large cities - debates in which linguistic issues played an important part. Further research is urgently needed to understand how discourses of endangerment and neoliberal discourses may in fact be serving or fuelling each other, despite apparently serving contradictory objectives. 


\section{Notes}

1 An earlier version of this paper was presented at the annual meeting of the American Anthropological Society in Montreal, November 2011, in a panel on potential bridges between Anglophone and Francophone sociolinguistics. I am grateful to the organisers of the panel, Alexandre Duchêne and Alexandra Jaffe, for letting me develop my ideas in that context. I would also like to thank Julia Sallabank and an anonymous reviewer for their extremely helpful and insightful comments on an earlier draft of this article. Finally, I thanks to Sara Brennan for her remarks on the structure and content of this paper. All remaining faults and flaws are my responsibility alone.

${ }^{2}$ In this respect, this article is situated within a tradition that seeks to reflect upon the conditions of the development of a stronger link between sociolinguistics and social theory (see, for example, Cameron 1990; Cameron et al. 1992; Carter and Sealey 2000; G. Williams 1992).

${ }^{3}$ Claude Hagège often appears in popular media, and is therefore fairly well-known among the general public.

${ }^{4}$ Occitan is a Romance language spoken in various dialects throughout the south of France. It has given rise to the development of an Occitan identity through the course of the twentieth century, and the Occitan movement remains one of the most dynamic language movements in France.

\section{References}

Amselle, J.-L. 2011. L'ethnicisation de la France. Paris: Editions Lignes.

Bauman, R., and C.L. Briggs. 2003. Voices of modernity: Language ideologies and the politics of inequality. Cambridge: Cambridge University Press.

Boas, F. 1911. Handbook of American Indian languages. Washington: Government Printing Office.

Bourdieu, P. 1977. The economics of linguistic exchanges. Social Science Information 16 : 645-668. 
Blommaert, J. 1999. The debate is open. In Language ideological debates, ed. J. Blommaert, 1-38. Berlin: Mouton de Gruyter.

Cameron, D. 1990. Demythologizing sociolinguistics. In Ideologies of language, ed. J.E. Joseph and T.J. Taylor, 79-93. New York: Routledge.

Cameron, D. 2007. Language endangerment and verbal hygiene: History, morality and politics. In Discourses of endangerment, ed. A. Duchêne and M. Heller, 268-285. London: Continuum.

Cameron, D., E. Frazer, P. Harvey, B. Rampton, and K. Richardson. 1992. Introduction. In Researching language: Issues of power and method. London: Routledge.

Carter, B., and A. Sealey. 2000. Language, structure and agency: What can realist social theory offer to sociolinguistics? Journal of Sociolinguistics, 4 : 3-20.

Costa, J. 2010. Revitalisation linguistique: Discours, mythes et idéologies. Approche critique de mouvements de revitalisation en Provence et en Ecosse. $\mathrm{PhD}$ diss., University of Grenoble. http://tel.archives-ouvertes.fr/AOM/tel-00625691/fr/

Costa, J. 2011. Du local au global: essai de clarification idéologique préalable. Discours concurrents et revitalisation linguistique en Provence. In Unité et diversité de la linguistique, ed. F. Manzano, 233-255. Lyon: Publications du Centre d'Etudes Linguistiques / Editions de l'université Jean Moulin, Lyon 3.

Costa, J., and M. Gasquet-Cyrus. To appear. What is language revitalisation really about? Competing revitalisation movements in Provence. In Keeping languages alive: Documentation, pedagogy and revitalisation, ed. M. Jones and S. Ogilvie. Cambridge: Cambridge University Press.

Craig, C. 1992. A constitutional response to language endangerment: the case of Nicaragua. Language, 68: 17-24. 
Dobrin, L., P.K. Austin and D. Nathan. 2009. Dying to be counted: the commodification of endangered languages in language documentation. In Peter K. Austin (ed.) Language Documentation and Description, Voume 6, 37-52. London: SOAS.

Dorian, N.C. 1981. Language death: The life cycle of a Scottish Gaelic dialect. Philadelphia: University of Pennsylvania Press.

Fishman, J.A. 1982. Whorfianism of the third kind: Ethnolinguistic diversity as a worldwide societal asset (The Whorfian hypothesis: Varieties of vValidation, confirmation, and disconfirmation II). Language in Society, 11: 1-14.

Fishman, J.A. 1991. Reversing language shift: Theoretical and empirical foundations of assistance to threatened languages. Clevedon: Multilingual Matters.

Foucault, M. 1980. Truth and Power. In Michel Foucault: Power/Knowledge. Selected interviews and other writings 1972-1977, ed. C. Gordon, 109-133. New York: Vintage Books.

Good. J. 2012. 'Community' collaboration in Africa: Experiences from Northwest Cameroon. In P.K. Austin and S. McGill (eds.) Language Documentation and Description, Volume 11. London: SOAS.

Grinevald, C., and J. Costa. 2010. Langues en danger: le phénomène et la réponse des linguistes. Faits de Langues, 35-36: 23-37.

Gruber, J.W. 1970. Ethnographic salvage and the shaping of anthropology. American Anthropologist, 72 : 1289-1299.

Hagège, C. 2000. Halte à la mort des langues. Paris: Odile Jacob.

Hagège, C. 2009. On the death andlife of languages. London: Yale University Press.

Hale, C.R. 2005. Neoliberal multiculturalism: The remaking of cultural rights and racial dominance in Central America. Political and Legal Anthropology Review, 28: 10-28. 
Hale, K., M. Krauss, L.J. Watahomigie, A.Y. Yamamoto, C. Craig, L.M. Jeanne, and N.C. England. 1992. Endangered languages. Language, 68: 1-42.

Heller, M., and A. Duchêne. 2007. Discourses of endangerment: Sociolinguistics, globalization and social order. In Discourses of endangerment: Ideology and interest in the defense of language, ed. A. Duchêne and M. Heller, 1-13. London: Continuum.

Hill, J.H., and K.C. Hill. 1980. Mixed grammar, purist grammar, and language attitudes in Modern Nahuatl. Language in Society, 9: 321-348.

Hill, J.H. 2002. "Expert Rhetorics" in advocacy for endangered languages: Who is listening, and what do they hear? Journal of Linguistic Anthropology, 12: 119-133.

Hinton, L. 2003. Language revitalization. Annual Review of Applied Linguistics, 23: 44-57.

Kroskrity, P.V. 2009. Language renewal as sites of language ideological struggle. The need for "ideological clarification.” In Indigenous language revitalization: Encouragement, guidance \& lessons learned, ed. J. Reyhner and L. Lockard, 71-83. Flagstaff, AZ: Northern Arizona University.

Labov, W. 2008. Unendangered dialects, endangered people. In Sustaining linguistic diversity, ed. K. A. King, N. Schilling-Estes, L. Fogle, J. J. Lou, and B. Soukup, 219238. Washington, D.C.: Georgetown University Press.

Lafont, R. 1971. Un problème de culpabilité sociologique: la diglossie franco-occitane. Langue française, 9 : 93-99.

Lafont, R. 1997. Quarante ans de sociolinguistique à la périphérie. Paris: L'Harmattan.

Lewis, H.S. 2001. The passion of Franz Boas. American Anthropologist, 103 : 447-467.

Martel, P. 2001. La France et l'occitan à l'époque contemporaine: histoire d'une étrange politique linguistique. In Dix siècles d'usages et d'images de l'occitan, ed. H. Boyer and P. Gardy, 367-384. Paris: L'Harmattan. 
Meyer, P., and J.M. Cuero. 2011. Indigenous language revitalization in Tecate, Baja California: A narrative account. In Ethnographic contributions to the study of endangered languages, ed. T. Granadillo and H.A. Orcutt-Gachiri, 57-76. Tucson, AZ: University of Arizona Press.

Moseley, C., ed. 2010. Atlas of the world's languages in danger. 3rd ed. Paris, UNESCO Publishing. Online version: http://www.unesco.org/culture/en/endangeredlanguages/atlas Mounin, G. [1992] 2006. Discussion - sur la mort des langues. In Pour une linguistique des langues, ed. H. Walter and C. Feuillard, 181-196. Paris: Presses Universitaires de France.

Muehlmann, S. 2008. "Spread your ass cheeks": And other things that should not be said in indigenous languages. American Ethnologist, 35: 34-48.

Muehlmann, S. In press. Von Humboldt's parrot and the countdown of last speakers in the Colorado Delta. Language and Communication, 32.

Pivot, B. To appear. Langue et territoire, quand l'un légitime l'autre. Le cas du rama au Nicaragua. Série monographique en sciences humaines / Human Sciences Monographic Series.

Robins, R.H., and E.M. Uhlenbeck. 1991. Endangered languages. New York: Berg.

Sarnoff, I. 1970. Social attitudes and the resolution of motivational conflicts. In Attitudes: Selected readings, ed. M. Jahoda and N. Warren, 279-284. Harmondsworth, UK: Penguin.

Skutnabb-Kangas, T. 2009. "The stakes: Linguistic diversity, linguistic human rights and mother-tongue-based multilingual education, or linguistic genocide, crimes against humanity and an even faster destruction of biodiversity and our planet”. Keynote 
presentation at the Bamako International Forum on Multilingualism, Bamako, Mali, 19-21 January 2009.

Speed, S. 2005. Dangerous discourses: Human rights and multiculturalism in neoliberal Mexico. Political and Legal Anthropology Review, 28: 29-51.

Swadesh, M. 1948. Sociologic notes on obsolescent languages. International Journal of American Linguistics, 14: 226-235.

Wallace, A.F.C. 1956. Revitalization movements. American Anthropologist, 58: 264-281.

Wallace, A.F.C. 2004. Foreword. In Reassessing revitalization movements: Perspectives from North America and the Pacific Islands, ed. M.E. Harkin. Lincoln: University of Nebraska Press.

Weir, L. 2008. The concept of truth regime. Canadian Journal of Sociology / Cahiers canadiens de sociologie, $33: 367-390$.

Williams, G. 1992. Sociolinguistics: A sociological critique. London: Routledge.

Williams, R. 1985. Keywords: A vocabulary of culture and society. Oxford: Oxford University Press.

Woodbury, A.C. 2011. Language documentation. In Peter K. Austin \& Julia Sallabank (eds.), The Cambridge Handbook of Endangered Languages, 159-186. Cambridge: Cambridge University Press. 